\title{
Case Study in a Malaysian Public Agency on an Asset Management-Moving Towards the Accrual Basis of Accounting
}

\author{
Sharifah Sabrina Syed $\mathrm{Ali}^{1}$, Sharon Cheuk Choy Sheung ${ }^{1} \&$ Mohd Waliuddin Mohd Razali ${ }^{1}$ \\ ${ }^{1}$ Faculty Economics \& Business, Universiti Malaysia Sarawak (UNIMAS), Malaysia \\ Correspondence: Sharifah Sabrina Syed Ali, Faculty Economics \& Business, Universiti Malaysia Sarawak \\ (UNIMAS), 94300 Kota Samarahan, Sarawak, Malaysia. E-mail: sassabrina@unimas.my
}

Received: March 16, 2019

Accepted: July 25, 2019

Online Published: July 26, 2019

doi:10.5430/afr.v8n3p149

URL: https://doi.org/10.5430/afr.v8n3p149

\begin{abstract}
As part of the strategic reform of Malaysian public services under the Government Transformation Program (GTP), accrual accounting is expected to be fully adopted in public sector financial reporting commencing on 1 January 2015, in order to ensure alignment with the global accounting standards. Consequently, in order to access the government effectiveness of moving towards the accrual basis of accounting, this study is to examine the asset management system in a Malaysian public agency; to evaluate the extent of compliance with MPSAS 17, Property, Plant and Equipment (PPE), IPSAS 26, Impairment of Cash-Generating Assets and IPSAS 21, Impairment of Non-Cash Generating Assets. Using qualitative approach, a preliminary study was conducted via interviews and through obtaining documents. The findings include the following: MPSAS17 has not been strictly adhered to and software is used to monitor the assets; however, the disposal of assets is a manual process and is not automated. The study also discussed any weaknesses pertaining to the said asset accounting system, and suggested recommendations for improvement thereon.
\end{abstract}

Keywords: accrual accounting, Malaysian public agency, asset accounting system

\section{Introduction}

\subsection{Accounting Reforms and the Rationale for Accrual Accounting}

Accounting reforms are part of the complex processes of social change, that in many cases stem from the need to define new surroundings for the role of government is called to play in this modern economy for the relationship between government and citizens (Caperchione \& Mussari, 2000). This is the reason why it is not possible to fully grasp the new policy that leading to accounting innovations in local government (ibid). According to Rozaidy, Raman, Rasid and Kaziemah (2014), to prepare for eventual adoption of accrual accounting, there must be change take place in the management where the structured approach for organization is supposed to occur. Despite the move of both federal and state governments towards accrual based accounting commencing from 2015, the newly elected government again proposed in Malaysian budget 2019 to once again include the use of accrual basis of accounting to replace the modified cash basis accounting. Xavier (2018) commented the full transition of accrual basis of accounting will be fully complied by 2021 meaning the extension still needed even after the commencement date.

Accrual accounting is a basis of accounting that is most commonly used by organizations around the world. Over a decade it has been more demands for accountability in the public sector where there is significant increasing in the number of governments all over the world using accrual accounting for financial reporting and budgeting purposes (Champoux, 2006). Accrual accounting is said to be beneficial for the government as like in the private sector, it can provide more information and can lead to a better decision making (Conolly \& Hyndman, 2011). Rozaidy et al. (2014) opined the shift towards accrual accounting demonstrates some problems and challenges. Hence, it is not sure as to whether the accrual accounting is being fully practice in the Malaysian public sector? Consequently, in order to access the government effectiveness of moving towards the accrual basis of accounting, this study intend to examine the transition of this new policy and whether there are differences can be found in the stages of economic development in the form of government practices of accrual basis, accounting traditions and in how accounting standards are set out and reviewed.

Under the accrual accounting, revenues are recorded when they are earned and expenses are recorded when they are incurred. In accrual accounting there is the term called accrued revenues which is a category of an asset and accrued 
expenses which is a category of liability. This contrasts with the cash basis of accounting, whereby revenues and expenses are recognized when they are received and paid in cash, respectively. Clearly, the accrual basis of accounting is more comprehensive in capturing transactions, as not all transactions are cash based; when adopted, it better reflects an organization's financial performance and position. Under the International Financial Reporting Standards this difference is summarized by IAS 37 which states: "11 Provisions can be distinguished from other liabilities such as trade payables and accruals because there is uncertainty about the timing or amount of the future expenditure required in settlement. By contrast: "(a) trade payables are liabilities to pay for goods or services that have been received or supplied and have been invoiced or formally agreed with the supplier; and "(b) accruals are liabilities to pay for goods or services that have been received or supplied but have not been paid, invoiced or formally agreed with the supplier, including amounts due to employees (for example, amounts relating to accrued vacation pay). Although it is sometimes necessary to estimate the amount or timing of accruals, the uncertainty is generally much less than for provisions. "Accruals are often reported as part of trade and other payables, whereas provisions are reported separately."

\subsection{Accrual Accounting in the Malaysian Public Sector}

The move to accrual accounting is part of the process adopting private sector accounting under the International Financial Reporting Standards. It is aimed to allow comparisons of the current cost of providing the service to the other public sector, not-for-profit, or private sectors. It is also part of the strategic reform of Malaysian public services under the Government Transformation Program (GTP), a policy measure in the New Economic Model (NEM). The NEM is an economic plan that was unveiled in Malaysia in 2010 and was expected to increase more than double the national per capita income by 2020. Among the key measures in NEM policy is Accrual-based accounting in public sector to strength and to improve public sector finance practices. According to the roadmap drawn by the Malaysian Institute of Accountants and the Malaysian Accounting Standards Board, accrual accounting will be fully adopted in public sector financial reporting commencing 1 January 2015, in order to ensure alignment with the International Public Sector Accounting Standards (IPSAS), issued by the International Federation of Accountants (IFAC), which are internationally accepted for current and future adoption. IPSAS have generally been used based on the International Financial Reporting Standards (IFRS). However, IPSAS may have standards is not obtainable in IFRS and IPSAS may use different terminologies to reflect the nature of public sectors entities. Implementation of the said IPSAS will involve the review of relevant Acts including the Federal Constitution, Financial Procedures Act 1957, Development Fund Act 1966 and Loan Acts and Housing Loan Fund Act 1971 (Pemandu, 2012). The Federal Government of Malaysia's financial statements will be prepared in accordance with the Malaysian Public Sector Accounting Standards (MPSAS), which have been adapted from IPSAS commencing year 2015. MPSASs are approved by the Government Accounting Advisory Committee and Accrual Accounting Steering Committee (AASC) under the Accountant General's Department. As of now, eleven MPSASs have been approved by AASC as follows:

MPSAS 1 - Presentation of Financial Statements,

MPSAS 2 - Cash Flow Statements,

MPSAS 3 -Accounting Policies, Changes in Accounting Estimates and Errors,

MPSAS 4 - The Effect of Changes in Foreign Exchange Rates,

MPSAS 9 - Revenue from Exchange Transactions,

MPSAS 12 - Inventories,

MPSAS 13- Leases,

MPSAS 16 - Investment Property,

MPSAS 17- Property, Plant and Equipment (PPE),

MPSAS - 23 - Revenue from Non- Exchange Transactions and

MPSAS 24 - Presentation of Budget Information in Financial Statements.

The adoption of accrual accounting is to aligned the financial practices of the Malaysian public sector with that of countries such as the US, UK, New Zealand, Australia, Canada, Colombia, France, Singapore and Japan, which have adopted the full accrual basis of accounting (Abdul Khan \& Mayes, 2009). In a PricewaterhouseCoopers survey published in 2013, of the 32 Organization for Economic Co-operation and Economic Development (OECD) countries, 59\% currently used accrual accounting for their central government accounts, whereas just $10 \%$ of the 68 
non-OECD countries surveyed said they currently used accrual accounting, but $60 \%$ planned to do so within the next five years (Mann, 2013). Recent report by IFAC (2019) 65\% of governments globally will report on an accrual basis by 2023 .

\subsection{Applying Accrual Accounting and Public Sector Accounting Standards to Property, Plant and Equipment}

The primary objective of most public sector bodies is to deliver services to the public rather than to make profits and make a return on equity to investors. In public sector, assets are held commonly to provide services, such as military assets, transportation infrastructure, national parks and mineral reserves. Under the cash basis of accounting, fixed assets are recorded only when they are paid for (JANM, 2002). Thus, a large capital acquisition will distort expenditure upward in the first year but the usage of that asset will not be recognized in following years (Graham, 2007). Concentration on cash payments alone will sometimes result in an unnoticed deterioration in fixed assets (Graham, 2007). This will lead to failure to accurately represent the amount of resource usage. Other problems include the undervaluation of assets, as no depreciation is provided for (JANM, 2002), which then leads to a lack of an effective balance sheet to reflect the true worth (or net debt) of the organization (Graham, 2007). Under the cash basis, not only the fixed assets are not depreciated, they are also not periodically revalued to take into account changing prices, which further compound the asset undervaluation problem. The cash basis of accounting for assets is also linked to frequent limited information about assets (Graham, 2007), leading to difficulty in effecting accountability over the said assets. A systematic approach for identifying, keeping track of, and valuing all assets and liabilities would encourage the development of systems (such as asset registers) and procedures for planning and management of assets and liabilities (Abdul Khan \& Mayes, 2009). Thus, the introduction of accrual accounting can promote a general improvement in the management of assets, as well as a heightened awareness of the cost of holding and deploying assets.

The public sector accounting standards relevant to fixed assets are: MPSAS 17, Property, Plant and Equipment(PPE) (Accountant General's Department Malaysia, 2013), IPSAS 26, Impairment of Cash-Generating Assets (IFAC, 2011) and IPSAS 21, Impairment of Non-Cash-Generating Assets (IFAC,2011). They are discussed in detail in the following paragraphs in this section.

MPSAS 17 covers the issues of asset recognition, measurement at recognition, cost or revaluation models, depreciation and depreciation methods, de-recognition, disclosure and transitional provisions. Recognition of PPE should take place if future economic benefits or service potential will flow to the entity, and the cost or fair value of the item can be reliably measured reliably. PPE should be measured at cost, which comprises the net purchase price plus purchase-related expenses, including installation costs. Thereafter, PPE should be carried at cost less any accumulated depreciation and any accumulated impairment losses. If a PPE's fair value can be reliably measured, it should be carried at a revalued amount, being its fair value at the date of the revaluation, less any subsequent accumulated depreciation, and subsequent accumulated impairment losses. Revaluations should be made with sufficient regularity to ensure that the carrying amount does not differ materially from that which would be determined using fair value at the reporting date. In terms of depreciation, each significant PPE item should be depreciated separately, and the residual value and useful life of an asset, together with the depreciation method, to be reviewed at least at each annual reporting date and, if expectations differ from previous estimates, the change(s) to be accounted for as a change in an accounting estimate. A PPE item is to be derecognized upon disposal or when no future economic benefit or service potential is expected from its use.

For each class of PPE, the following is to be disclosed: the measurement bases used for determining the gross carrying amount, depreciation methods used, useful lives or the depreciation rates used, gross carrying amount and the accumulated depreciation (aggregated with accumulated impairment losses) at the beginning and end of the period, and a reconciliation of the carrying amount at the beginning and end of the period showing additions, disposals, acquisitions through entity combinations, revaluation increases or decreases, impairment losses recognized or reversed, depreciation, foreign translation differences and other changes. Other required disclosures, usually in the notes to the financial statements, include the existence and amounts of restrictions on title, and PPE pledged as securities for liabilities, the amount of expenditures recognized in the carrying amount of a PPE item in the course of its construction, the amount of contractual commitments for the acquisition of PPE, and the amount of compensation from third parties for PPE items that were impaired, lost or given up. If a class of PPE is stated at revalued amounts, the following need to be disclosed: the effective date of the revaluation, whether an independent valuer was involved, the methods and significant assumptions applied in estimating the assets' fair values, the extent to which the assets' fair values were determined directly by reference to observable prices in an active market or recent market transactions on arm's length terms, or were estimated using other valuation techniques, the revaluation surplus, 
indicating the change for the period and any restrictions on the distribution of the balance to shareholders or other equity holders, the sum of all revaluation surpluses for individual PPE items within that class, and the sum of all revaluation deficits for individual PPE items within that class. Transitional provisions are available for entities which are in the initial stage of adopting IPSAS accrual accounting. For instance, entities are not required to recognize PPE for reporting periods commencing within 5 years following the date of first adoption of IPSAS accrual accounting. PPE can be initially recognized at cost or fair value.

IPSAS 21 and 26 refer to the recognition of impairment losses for PPE, whereby IPSAS 21 relate to non-cash-generating assets, while IPSAS 26 relate to cash-generating assets. Impairment is defined as a loss in the future economic benefits or service potential of an asset, over and above what has been deducted as depreciation. An asset is impaired when its carrying amount exceeds its recoverable amount or recoverable service amount; any potential impairment is assessed at each reporting date. Recoverable amount is the higher of an asset's fair value less costs to sell and its value in use. For cash-generating assets, the value in use can be obtained by estimating the present value of future cash inflows and outflows to be derived from the continuing use of the asset and from its ultimate disposal; for noncash-generating assets, the value in use is the present value of the remaining service potential of the asset, which can be determined using either the depreciated replacement cost approach, restoration cost approach or service unit approach. An impairment loss is recognized if the recoverable amount is less than the carrying amount. Cash-generating units should be identified consistently from period to period for the same asset or types of assets, unless a change is justified. The re-designation of assets from cash-generating assets to non-cash-generating assets or vice versa would need to be performed when appropriate.

\subsection{Theory of Organizational Readiness for Change}

The theory of organizational readiness for change was suggested by Weiner (2009) based on social cognitive theory and self-efficacy theory (Gist and Mitchell, 1992). It consists of multi-level and multi-faceted constructs. The theory of organizational readiness for change postulates that readiness comprises two modules, that is, change commitment and change efficacy; it is a function of the three aspects of change valance, task knowledge and task availability (Weiner, 2009). In standard language, the term "readiness" refers to "a state of being both psychologically and behaviorally prepared to take action" with regards to the change (Weiner, 2009). He defined organizational readiness as change commitment and change efficacy among organization members to implement organizational change. This theory is applied in the New Zealand public sector where it experienced major reform between late 1980's and early 1990's. This reform changed public sector management from a system based on compliance with detailed and restrictive rules and budget cash limits to a performance and accountability-based regime (IFAC, 1994).

New Zealand and Australia are the countries that is often cited as having adopted accrual accounting more comprehensively than any others (Champoux, 2006). Champoux (2006) concluded that most observers have found the reforms in New Zealand and Australia have been a success, though most also believe the reforms remain a work in progress. This study is guided based on the theory of organizational readiness for change and the finding of prior literature on New Zealand experience in implementing accrual accounting in government.

\section{Study Objectives and Research Methodology}

The objective of this study is to examine the asset management system in a Malaysian public agency and to ascertain the extent of its compliance with MPSAS 17, IPSAS 21 and IPSAS 26. Any weaknesses are highlighted and recommendations proposed thereon. Data received from interviews from a public university located in East Malaysia in the year end 2014. An illustrative case study is employed which are primarily descriptive studies.

This study adopted the qualitative case study approach due to the investigative nature of the research. Support for this approach has been noted from Miles and Huberman (1994), who used alternative analytic techniques of analysis within the case study design, and Yin (1994), who designed specific protocols for conducting the case study. Both Miles and Huberman (1994) and Yin (1994) opined that the case study approach added confidence to findings and increased study reliability. Other researchers using this approach including Meredith (1998) and Dubois and Araujo (2007); Deaconu et. al (2011) also used this approach within the public sector accounting context. A preliminary study was conducted via interviews, following a set of interview protocol which includes general instructions and a list of questions to be asked (Perry, 1998). A total number of five participants became the interviewees in this study. In this study, five participants are adequate enough to address the problem as it is a case study in a Malaysian public agency. Among the participants are one account assistant, two account executives, IT personnel and an administrator. The inclusion of those participants is adequate enough as it represents the people from the account department pertaining to asset management. The documents obtained prior to conducting the study were as follows: 
(a) asset management procedures;

(b) process flowchart for the disposal of assets;

(c) process flowchart for the write-off of movable assets; and

(d) process flowchart for loss and write-offs of assets in general.

\section{Background of the Case Study}

The accounting of assets is administered by the Asset Unit, under the purview of the Bursar's office, which is staffed by 3 personnel. This division was established in 2008 under the advice of the Jabatan Audit Negara; previously, the said unit was part of the Accounts Department. Assets are generally categorized into "General Assets" and "Movable Assets". "General Assets" refer to property owned, in the possession or under the control of the agency, purchased, received through donations or gifts or obtained through the legislative process. "Movable Assets" refer to assets that can be transferred from one place to another, including assets that are supplied or installed together with the building. Such mobile assets are divided into two groups, namely "Capital Assets" and "Inventory". "Capital Assets" are those with original acquisition price of RM3,000 and above per unit and with a shelf life of longer than one year, or those that require regular maintenance regardless of the original acquisition price. "Inventory" refer to movable assets with original acquisition price of less than RM3,000 per unit, with a shelf life of longer than one year and which does not require regular maintenance. "Inventory" also include furniture and fixtures, carpeting, furnishings, curtains, tableware sets and knowledge resources regardless of the original acquisition price.

The asset management system (AMS) covers acquisition/acceptance, registration, use/storage/inspection and maintenance. In acquisition/acceptance, assets received are ensured to meet specifications, that the actual quantity and quality of the assets acquired agree with that on the acquisition order, and that the assets were received in good condition and were safe to use. Under registration, AMS creates a database with complete, accurate and up-to-date information to facilitate detection and monitoring, know the condition of the assets and to facilitate maintenance, disposal and replacement. Under use/storage/inspection, assets are ensured that they are not used in a wasteful manner, abused or lost. Lastly under maintenance, assets are ensured to be in good condition and function smoothly. Software is used to monitor the assets. The unit utilized Integrated Financial Accounting the System (IFAS) PeopleSoft, which was used to generate journals and the general ledger and for checking payments. The unit has recommended to the Internal Audit Department to adopt the government-recommended system Sistem Pengurusan Aset Kerajaan (SPAK), which will allow for easier monitoring of assets.

\section{Results and Discussions}

It was noted that every Responsibility Centre (RC) is not able to login to directly enter new assets into the system; currently, details of assets are only inputted into the Asset Management System (AMS) after payment is made. The point of recognition of an asset, therefore, is the payment date; where assets are concerned, the cash basis of accounting and not the accrual basis is followed. Hence, from the asset recognition perspective, MPSAS 17 has not been strictly adhered to. However, this is partially mitigated in the year end closing process, where any payments after the year end, in respect of asset acquisitions before the year end, are backdated so that the asset purchase is captured in that year. During this adjusting period, the IT department is requested to block the system to prevent any $\mathrm{RC}$ from entering next year asset acquisitions. According to the account departments, this is to ensure that the cut-off period takes place.

The depreciation is charged straight line at rates ranging from $2 \%$ to $33.3 \%$ per annum, depending on the asset category, and the depreciation methods are approved by the Jabatan Audit Negara. Freehold land is not depreciated, whereas leasehold land is depreciated over the number of years of the lease. Fixed buildings are depreciated at $2 \%$ while temporary buildings are at $10 \%$. Infrastructure is depreciated at $5 \%$; while office equipment, fixtures and fittings, motor vehicles and machinery, teaching and research tools, sports, arts and leisure equipment, books and library equipment, telephone and communication tools, photographic and filmography tools and convocation tools are all charged at $20 \%$. Computer and related tools are depreciated at $33.3 \%$. Construction in progress is valued at cost and depreciation is not charged. Upon completion, construction in progress is transferred to the relevant PPE category.

Meanwhile, the depreciation is charged according to IPSAS 27. However, PPE is not measured at fair value and impairment loss is not considered. Furthermore, revaluation was not regularly conducted, although we were informed that one valuation exercise was done recently as the result of an audit recommendation. We were also informed that the depreciation charge for every asset is separately calculated every year and manually entered into the PeopleSoft 
software, as it does not have a function which automatically calculates depreciation using a given depreciation method and rate. This may give rise to calculation errors and cause the final asset values to be under or overstated.

In terms of asset additions, we noted that very few were made during the year - only 7 as at the date of our fieldwork. These include research-related assets such as machines and laboratory equipment. As quoted form one of the account executives, "we only know the purchases been made once the RC's approved on the purchase order and thereafter we proceed with the processing of the payment pertaining to the asset acquisitions". We were informed that all purchases were made in accordance with the budgets set by the respective RCs. On the other hand, the disposal of assets is governed by set of procedures. If the disposal relates to an ICT item, it will be handled by the IT Department; for non-ICT items, the Asset Management Department will handle it. The asset disposals can be effected in the following ways: tender, auction, waste sales, barter-trade, trade-in, cannibalization, transfer, gift or destruction. Generally, disposal of assets is a manual process and not automated, and can be a long process from beginning to the end.

Assets are disposed of according to the following procedures. First, assets to be disposed of are identified, and their details (such as description, quantity, date of purchase, original acquisition value, and its present value) are noted on a form. The assets are then inspected and the examiners sign on the same form, which is then submitted to a disposal secretariat. The secretariat will then ensure that relevant documents are attached to the form, such as justification for the recommended method of disposal, a photo of the assets (for ICT equipment), an accident report (for a motor vehicle involved in accident), (for Non- ICT), letter of application for the method of disposal. The Treasurer is then informed. The application is then submitted to the Treasurer for approval if original asset acquisition value or total does not exceed RM350,000; to a second higher authority if value/total does not exceed RM700,000; to the highest level of authority if value/total does not exceed RM1,000,000; and to the Finance Committee if the total of asset is more than RM1,000,000. Approval decision is then informed to the applicant and disposal is then executed accordingly. The final document is the Certificate of Disposal which needs to be submitted to the Treasurer's Office together with a copy of the sales receipt for the disposal method, the acknowledgment letter for the disposal method or Certificate of Destruction for assets destroyed.

Lastly, the asset register records are updated. Asset write-offs are effected when assets are no longer in existence due to theft, accident, fire, natural disaster, loss, fraud or negligence of public officers. Write-off is a process to cancel the lost asset records. Asset write-offs are intended to control the losses incurred due to asset loss coordinate the asset records, to promote awareness and responsibility for the security of the assets, and to allow surcharges and/or disciplinary action to be imposed on negligent officials. The Treasurer's Office is the secretariat for the loss and write-offs with the cooperation of the General Administration and Security. The secretariat first obtains information about the missing assets from the Capital Asset Register or Inventory, and obtains the Preliminary Report and a copy of the police report from the RC concerned. An Investigating Committee is set up to obtain the results from the respective police investigations, and the Committee will then produce the Final Report which will be submitted for review and recommendation by the Controlling Officer. The application documents are then submitted to the Approving Authority within two (2) months from the submission date of the Preliminary Report and the police investigation report. The Approving Authority's decision is then informed to the RC for action updates to be made to the asset register records. Surcharge or disciplinary recommendations are also made to the Disciplinary Board for further action. We were informed that assets were usually lost because they were borrowed but not returned, and the borrowing was not informed to the RC concerned. In most cases, assets lost were laptops. We also were informed that in $70 \%$ of the asset losses, write-offs were not affected and the said assets remained in the system. This would not be in compliance with IPSAS as a PPE item should be derecognized upon disposal or when no future economic benefit or service potential is expected from its use. As such, the total PPE would be overstated in view of the continued inclusion of the lost assets in the asset listing. To mitigate this, the cost of the lost asset, at current market value, would be charged to the officer responsible; however, enforcement has not been consistent.

The PeopleSoft software is not able to generate detailed asset listings, especially depreciation charge by individual asset. Therefore, auditors would not be able to check the correctness of the depreciation calculations. It is also noticed that the assets written off and assets disposed are compiled in the same list and need to be manually highlighted to differentiate the two categories. For the purpose of effective asset monitoring, these categories should be automatically separated. Other general weaknesses noted include the fact that due to regular staff reshuffling, the procedures and guidelines for asset management, and any audit recommendations, may not be properly passed on to the new staff-in-charge. Also, not all staff in the Asset Unit were aware of the compulsory adoption of IPSAS by 2015. Thus by the end of year 2019, it is expected that through continuous staff training and fully adoption of IPSAS 
they are all aware of the changes of accounting standards required by the Malaysian government and is expected that they fully implement the IPSAS.

\section{Conclusion and Recommendations}

The objective of this study was to examine the asset management system in a Malaysian public agency and to ascertain the extent of its compliance with MPSAS 17, IPSAS 21 and IPSAS 26, as well as to highlight any weaknesses and propose recommendations thereon. Based on our findings, the agency under study is not in full compliance with MPSAS 17 and IPSAS 21 and 26. The difference may be due to the timing and speed of change required by government. However, in view of the fact that the study took place during the GTP reform, there is still time to rectify the current system and it would be an avenue for future study to revisit the agency on its progress. Furthermore, as mentioned earlier, transitional provisions are available for entities which are in the initial stage of adopting IPSAS accrual accounting. For instance, entities are not required to recognize PPE for reporting periods commencing within 5 years following the date of the first adoption of IPSAS accrual accounting. Therefore, the agency can make use of the intervening period to make the necessary changes in the asset accounting/management system to ensure full compliance with the relevant IPSAS's.

The main adjustment that is needed is related to the point of recognition of PPE acquisition. The standard accounting procedures must be changed so that once an asset item is purchased and ownership is transferred to the agency, input must be made into the accounting system accordingly. Such changes must be disseminated to all relevant personnel through formal instruction and via training/workshops, and the subsequent actual actions must be monitored for compliance and accuracy thereof accordingly. Other recommendations are as follows: All asset losses should be written off and excluded from the asset listing once they are confirmed to be irrecoverable. Physical count on assets should be made by RCs at least yearly although the bar-coding system is being implemented on asset purchased. Rectifications that should be made include regular review of PPE for impairment; PPE should also be regularly revalued to ensure that assets are more accurately stated at fair value. The PeopleSoft software needs to be replaced or customized accordingly to allow for automatic calculation of depreciation, and to generate detailed asset listings for review by auditors. The capability to generate separate listings for assets disposed or written off in a year is also necessary. In general, all relevant staff should be well-apprised of the requirements of IPSAS, via external training in government-led workshops. More professional and senior personnel in the accounting field could also be utilized in the advisory role. Since, this study only involved one government agency, future study can include more public sector agencies to be the participants.

\section{Acknowledgement}

This work was supported by Universiti Malaysia Sarawak [grant number SGS/03(S118)/901/2013(02)].

\section{References}

Abdul K. \& Mayes, S. (2009). Transition to Accrual Accounting, Technical Notes and Manuals09/0. Retrieved March 3, 2014 from http://blogpfm.imf.org/files/fad-technical-manual-2.pdf. http://dx.doi.org/10.5089/9781462371730.005

Accountant General's Department Malaysia. (2011). MPSAS 17, Property, Plant and Equipment. Retrieved March 31, 2014 from http://www.ifac.org/sites/default/files/publications/files/ipsas-17-property-plant-3.pdf.

Azmi, A.H. \& Mohamed, N. (2014). Readiness of Malaysian public sector employees in moving towards accrual accounting for improve accountability: the case of ministry of education (MOE). Procedia-Social and Behavioral Sciences, 164, 106-111.

Caperchione, E. \& Mussari, R. (2000). Comparative Issues in Local Government Accounting. Springer, Boston, MA https://doi.org/10.1007/978-1-4615-4581-1

Champoux, M. (2006). Accrual Accounting in New Zealand and Australia: Issues and Solutions, Harvard Law School Federal Budget Policy Seminar, Briefing Paper No.27 Retrieved July 18, 2018 from http://lawweb.usc.edu/cslp/conferences/fiscal\%20challenges/documents/13-FASAB.pdf

Conolly, C. \& Hyndman, N. (2011). Accruals Accounting in the Public Sector: A Road Not Always Taken, Management Accounting Research, 22(1), 36-45. https://doi.org/10.1016/j.mar.2010.10.008

Deaconu, A., Nistor, C.S. \& Filip, C. (2011). The Impact of Accrual Accounting on Public Sector Management: An Exploratory Study for Romania. Transylvanian Review of Administrative Sciences, 32(E/2011), 74-97. https://ssrn.com/abstract=1911285 
Department of the National Accountant of Malaysia (JANM) (2002). Government Accounting Policy. Putrajaya: JANM. Retrieved March 3, 2014 from www.anm.gov.my/public_html/borang/ppk_1.pdf.

Dubois, A. \& Araujo, L. (2007). Case Research in Purchasing and Supply Management: Opportunities and Challenges. Journal of Purchasing \& Supply Management, 13 (3), 170-181. https://doi.org/10.1016/j.pursup.2007.09.002

Gist, M.E. \& Mitchell, T.R. (1992). Self-efficacy: a theoretical analysis of its determinants and Malleability. Academy of Management Review, 17(2), 183-211. https://doi.org/10.2307/258770

Graham, A. (2007). Canadian Public Sector Financial Management. McGill-Queen's University Press.

IFAC (1994). Occasional paper 1 - implementing accrual accounting in government: The New Zealand Experience, International Federation of Government, New York, NY.

International Financial Reporting Standards, IAS 37-Provisions, Contingent Liabilities and Contingent Assets. $\begin{array}{llll}\text { Retrieved } & \text { May } & 22, & \text { from }\end{array}$ http://www.ifrs.org/IFRSs/IFRS-technicalsummaries/Documents/IAS37-English.pdf

International Federation of Accountants (IFAC). (2011). IPSAS 21, Impairment of Non-Cash-Generating Assets.

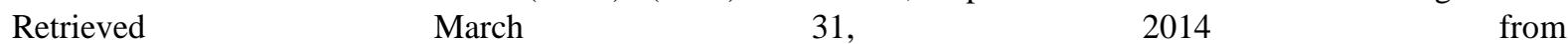
https://www.ifac.org/sites/default/files/publications/files/ipsas-21-impairment-of-no.pdf.

International Federation of Accountants (IFAC). (2011). IPSAS 26, Impairment of Cash-Generating Assets.

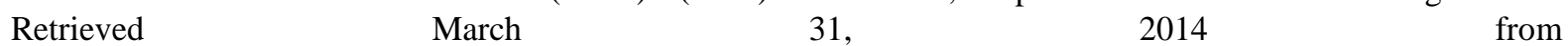
https://www.ifac.org/sites/default/files/publications/files/ipsas-26-impairment-of-ca-2.pdf.

IFAC (2019). 65\% of Governments Globally Will Report on an Accrual Basis by 2023, Finds New Report. Retrieved July $18, \quad 2019 \quad$ from https://www.ifac.org/news-events/2018-11/65-governments-globally-will-report-accrual-basis-2023-finds-new-r eport

Mann, N. (2013). Governments using accrual accounting set to soar. Retrieved April 7, 2014 from http://www.publicfinanceinternational.org/news/2013/05/governments-using-accrual-accounting-set-to-soar/

Meredith, J. (1998). Building Operations Management Theory through Case and Field Research. Journal of Operations Management, 16 (4), 441-454. https://doi.org/10.1016/S0272-6963(98)00023-0

Miles, M.B. \& Huberman, A.M. (1994). Qualitative Data Analysis. 2nd edition, Thousand Oaks, CA: Sage Publications.

Performance Management \& Delivery Unit (Pemandu), (2012). Economic Transformation Programme, Public Finance Reform, Accrual Accounting. Retrieved March 21, 2014 from http://etp.pemandu.gov.my/Public_Finance_Reform-@-Accrual_Accounting.aspx

Perry, C. (1998). Processes of a Case Study Methodology for Postgraduate Research in Marketing. European Journal of Marketing, 32 (9/10), 785-802. https://doi.org/10.1108/03090569810232237

Rozaidy M., Raman, N., Rasid M. \& Kaziemah, S. (2014). Accrual Accounting in Malaysia: What We Should Learn from Others. Malaysian Journal of Business and Economics, 1(2), 63-76.

Weiner, B.J. (2009). A theory of organizational readiness for change. Implementation Science, 4(1), 67. https://doi.org/10.1186/1748-5908-4-67

Xavier, J.A. (2018, November 8). 2019 budget: It merits our favour. New Straits Times, 1. Retrieved from https://www.nst.com.my/opinion/columnists/2018/11/429258/2019-budget-it-merits-our-favour

Yin, R.K. (1994). Case Study Research: Design and Methods. (2nd edition). London: Sage Publication. 